\title{
Mathematical model of energy production, used to support energy policy in local government units
}

ABSTRACT: The agrarian process includes many industrial phenomena and events. The goal of economics as a science is to precisely detect and describe the relationships between various market mechanisms. These phenomena can be presented as the desire "to describe reality in terms of systems, their components and relationships, both between components of the system and between different systems" (Jankowski 1997). The energy sector is a special field among many areas of the national economy, and the products of this sector have a major impact on the branches of the economy and the mechanisms of action occurring in them. The publication is devoted to the construction of a mathematical model used to support the energy policy of local government units. The aim of the study is to build a mathematical model of energy production, taking the development potential of renewable energy into account, as well as to propose the desired direction of energy policy development in the analyzed periods to the regional authorities and to offer a model for creating an energy policy in other local government units: poviats, communes. Until now, few authors have comprehensively dealt with this issue. To date, no detailed research has been published on issues related to renewable energy development and the use of mathematical methods in the construction of the energy production model in local government units. The undertaken research is a contribution to the development of knowledge about alternative energy sources in the energy margin.

KEYWORDS: renewable energy sources, lexicographic method, mathematical model of energy production

$\triangle$ Corresponding Author: Marcin Rabe; e-mail: marcin.rabe@wzieu.pl

1 Management Institute, University of Szczecin, Szczecin, Poland; ORCID iD: 0000-0002-4817-1971; e-mail: marcin.rabe@wzieu.pl

2020. The Author(s). This is an open-access article distributed under the terms of the Creative Commons Attribution-ShareAlike International License (CC BY-SA 4.0, http://creativecommons.org/licenses/by-sa/4.0/), which permits use, distribution, and reproduction in any medium, provided that the Article is properly cited. 


\section{Introduction}

The economic process includes many economic phenomena and events. The goal of economics as a science is to precisely detect and describe the relationships between various economic phenomena.

Therefore, operational research allows, using mathematical and economic models, the practical determination of the methodology for solving specific economic phenomena, making optimal decisions in various specific situations. Operational research is particularly often used to solve economic and production problems.

These phenomena can be presented as "seeking to describe reality in terms of systems, their components and relationships, both between system components and between different systems" (Jankowski 1997).

The present article attempts to build a mathematical model of energy production using the lexicographic method.

The methodical goal of the article is to build a mathematical model of energy production taking the potential for the development of renewable energy into account, taking the criteria of sustainable development into account, i.e. economic, ecological, and social. The purpose of the article is also to propose to the regional authorities the desired direction of energy policy development and to offer a mathematical model of energy production for creating energy policy in local government units: poviats and communes. Until now, few authors have comprehensively dealt with this issue. To date, no detailed research has been published regarding the issues of renewable energy development and the use of mathematical methods in building the energy production model in local government units. The undertaken research is a contribution to the development of knowledge regarding alternative energy sources in the energy sector (Theo et al. 2017)

\section{Model definition}

The systemic approach assumes that the studied reality is too complex to be fully known. Therefore, he postulates the replacement of the examined, complex object with his model, i.e. simplified images of economic reality, where the use of simplifications results from the complex nature of economic phenomena, and the deliberate omission of certain relations allows you to focus on the selected phenomenon (Sobczyk et al. 2011).

According to Bartoszewicz, the model is a system of functions (in a particular case of one function, usually many variables, although in the simplest case it can be a function of one variable), approximating the described fragment of economic reality (Bartosiewicz 1990). Another 
definition in the literature is given by Zieleniewski, who believes that the model is a theory constructed in such a way that it is possible to manipulate the variables that make up it. It is used not only for orientation in the real environment, but also for replacing the real experiment with reasoning consisting in changing the value of individual variables and checking the consequences it causes in relation to other variables (Glinkowska 2010).

To solve the model, methods of linear and nonlinear programming, dynamic programming, probability theory, game theory, mathematical statistics etc. may be used. There are many types of decision models, depending on the results of decision making and the type of decision problem. The most useful models for management purposes are (Bhowmik et al. 2017):

$\checkmark$ linear programming models,

$\downarrow$ nonlinear programming models,

$\checkmark$ dynamic programming models,

$\checkmark$ network models,

$\downarrow$ decision tree,

$\checkmark$ simulation model (Monte Carlo).

Most optimization models consist of three basic parts:

1) purpose function,

2) restrictive conditions,

3) the condition of non-negativity of decision variables.

The use of decision models in the approach to energy management issues allows for the formulation of a number of system methods and solutions (Krog and Sperling 2019).

Simple solutions can be determined for linear systems when the impact on the quality of the environment can be expressed using so-called environmental costs. Very often, however, we cannot assume the linearity of data dependencies due to the simultaneous operation of many different types of factors affecting the decision-making process. This creates the possibility of using multi-criteria approach to the problem (Rabe et al. 2019a).

\section{Multi-criteria methods in planning energy production}

When building an energy model in a given area, attention should be paid to the problem of decision selection and energy production planning. Each decision sometimes has very far-reaching effects, and its consequences are often very complex. If the optimal variant is selected in planning energy production in a given area, the choice must be multi-faceted, taking various problems into account. When assessing variants of energy production, one cannot rely only on the financial analysis of investments, but one should also take very important issues, such as: environmental aspects (ecological costs, loss of soil fertility), agroenergetic aspects, technological aspects, organizational aspects and social aspects into account (Rabe et al. 2019b). 
The decision to choose a project implementation variant in planning energy production in a given area also requires examining the options for their positive and negative impact. The positive aspects include benefits and opportunities, while the negative aspects include costs and risks. The problem with assessing these aspects often lies in the difficulty of expressing them in numerical terms. For example, some benefits are qualitative, even environmental or risk elements (Skoczkowski 2007).

A decision is often a random or purely intuitive choice, not supported by any analysis or strategy planning. To avoid errors and randomness of choice, it is necessary to set criteria and objectives of the activity before planning the energy model of the studied area. Therefore, goals can be of various types:

$\checkmark$ competitive goal - when increasing the value of one of the goals results in lowering the implementation of the other, e.g. maximizing profit and increasing the size of its risk,

$\downarrow$ interconnected goals that have a relationship in that progress in achieving one goal is accompanied by an increase in the other,

$\checkmark$ complementary objectives that support each other,

$\checkmark$ supplementary goals - independent of each other, reducing or increasing the implementation of one does not affect the size of the other (Malicki 1999).

The relationships described between the individual goals are not permanent. One of them may change into the other, depending on the size of absolute production for the needs of renewable energy. The goals can also be complementary, i.e. complement each other in the use of one factor of production, and at the same time compete with each other for another.

The nature of the relationship between the individual criteria is difficult to determine. Their formation can be observed only in the process of optimization of the mathematical model of the energy production plan in a given area. The task in model planning is to construct a production plan that maximally achieves individual goals in line with its preferences (Malicki 1993).

Therefore, when planning energy production, resorting to proven scientific methods is necessary. These include multi-criteria methods. Three groups of such methods are most widely used:

The distance function method, where for each set of multi-criteria task solutions one can set a certain reference point in the criterion space against which individual solutions are assessed. This point can be an ideal point or any other point at which the values of individual goal functions meet the expectations of the decision-maker.

In the classical method of the distance function, the optimal solution is the one whose image in the criterion space is located as close as possible to the (furthest) reference point, i.e. the distance of this point from the reference point is minimal (maximum) (Konarzewska-Gubała 1980).

The utility function method - in this method, to determine the solution of a task, a certain aggregate function specified on the set of criteria functions, called the utility function, is introduced, which is then maximized (minimized), thus reducing the problem of multi-criteria optimization to the solution of a single-criteria task.

It is assumed that in order for a utility function to be used, it should maintain a strict order in a set of partial objective functions, which means that an increase in the value of each criterion 
function increases the value of the utility function. The main disadvantage of this method is the very high sensitivity of the result to the selection of criteria. In practice, the decision-maker is not able to justify the precise separation of criteria, but only to estimate their approximate values, and a small error in this estimate can diametrically change the result (Kasprzak 1992).

The Lexicographic method - requires the prioritization of criteria, followed by ordering variants in order to maximize the values of these criteria in order. This method allows you to get a ranking in a short time, even without the help of a computer, however, it requires assuming priority criteria.

The basic features of the lexicographic method are:

$\checkmark$ a clear interpretation of the solutions obtained,

$\checkmark$ the possibility of taking a larger number of functionals than in other multi-criteria methods into account, no need to consider the substitutability of individual criteria,

$\checkmark$ the possibility of using for large optimization tasks, the possibility of considering various types of criteria in the task: linear, quotient, non-linear, dialogic nature allowing to continue the procedures until a compromise satisfying the user is obtained (Mokrzycki 2003).

Disadvantages of the lexicographic method:

$\checkmark$ no guarantee that the solution obtained is pareto-optimal,

- laboriousness of the method - to obtain a compromise solution satisfying the user is achieved by multi-criteria repetition of calculations, in each case verifying the initial, determined threshold values or acceptable deviations from the maximum values.

To some extent, these drawbacks are compensated by the simplicity of calculations, a clear interpretation of the procedure and the introduction of structural variables into the calculation program that allows the values of all relevant parameters to be obtained for each solution.

\section{Application of the lexicographic method in the construction of a mathematical model of energy production}

The application of the lexicographic method allows a mathematical model of electricity production from renewable sources in the studied area to be built, the solution of which will be characterized by the following features:

$\checkmark$ the minimum cost of electricity production;

$\downarrow$ the maximum level of use of renewable energy;

$\downarrow$ minimal impact on the environment.

You can enter the following decision variables in the model:
$\mathrm{x} 1 \quad-$ conventional energy production $[\mathrm{kWh}]$;
x2 - energy production from co-firing [kWh];
$\mathrm{x} 3-$ hydropower production $[\mathrm{kWh}]$ up to the day specified; 


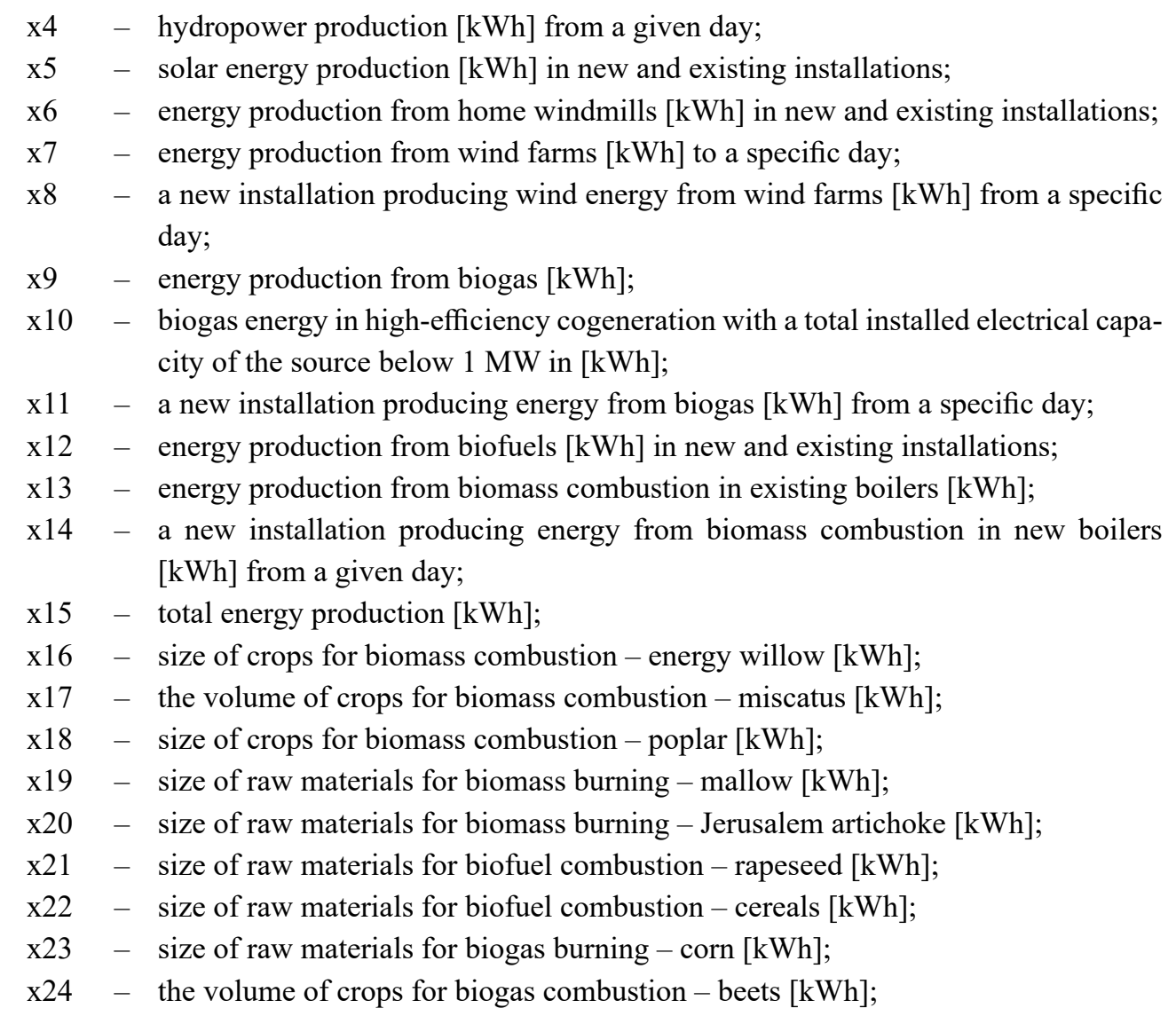

The variable unit in the energy production model is $\mathrm{kWh}$.

The purpose function of the energy production model will consist of production costs, certificates, ecological costs, EUA allowance costs and energy storage costs for each type of energy (variable from $\mathrm{x} 1$ to $\mathrm{x} 14$ ) and loss of soil fertility caused by their exploitation in the production of raw materials for biomass, biogas, biofuels and agricultural commodity production (variables from $\mathrm{x} 16$ to $\mathrm{x} 24)$.

In the optimization model, only one function $(\mathrm{L}(\mathrm{x}))$ is minimized, which is a component of the above components.

$$
\begin{gathered}
\mathrm{L}(\mathrm{x})=\mathrm{x} 1+\mathrm{x} 2+\mathrm{x} 3+\mathrm{x} 4+\mathrm{x} 5+\mathrm{x} 6+\mathrm{x} 7+\mathrm{x} 8+\mathrm{x} 9+\mathrm{x} 10+\mathrm{x} 11+\mathrm{x} 12+\mathrm{x} 13+\mathrm{x} 14+\mathrm{x} 16+ \\
\mathrm{x} 17+\mathrm{x} 18+\mathrm{x} 19+\mathrm{x} 20+\mathrm{x} 21+\mathrm{x} 22+\mathrm{x} 23+\mathrm{x} 24 \rightarrow \min
\end{gathered}
$$

Side variables of the energy production model are the following variables (boundary conditions assume that all variables must be non-negative):

$$
\mathrm{x} 1+\mathrm{x} 2+\mathrm{x} 3+\mathrm{x} 4+\mathrm{x} 5+\mathrm{x} 6+\mathrm{x} 7+\mathrm{x} 8+\mathrm{x} 9+\mathrm{x} 10+\mathrm{x} 11+\mathrm{x} 12+\mathrm{x} 13+\mathrm{x} 14=\mathrm{x} 15 \text { total energy }
$$


$\mathrm{x} 15=\mathrm{x} \mathrm{kWh}-$ energy production for the region

$\mathrm{x} 3+\mathrm{x} 4+\mathrm{x} 5+\mathrm{x} 6+\mathrm{x} 7+\mathrm{x} 8+\mathrm{x} 9+\mathrm{x} 10+\mathrm{x} 11+\mathrm{x} 12+\mathrm{x} 13+\mathrm{x} 14 \geq \mathrm{x} 15-$ renewable energy must represent at least $\mathrm{x} \%$ of total energy production

$\mathrm{x} 6+\mathrm{x} 7+\mathrm{x} 8 \leq \mathrm{x} \mathrm{kWh}-$ the amount of energy produced by windmills

$\mathrm{x} 9+\mathrm{x} 10 \leq \mathrm{xkWh}-$ biogas production

$\mathrm{x} 1=\mathrm{x} \mathrm{kWh}-$ maximum conventional energy production

$\mathrm{x} 2 \leq \mathrm{x} \mathrm{kWh}-$ maximum energy production from co-firing

$\mathrm{x} 3 \leq \mathrm{x} \mathrm{kWh}$ - hydropower production

$\mathrm{x} 4=\mathrm{x} \mathrm{kWh}-$ production of new hydropower

$\mathrm{x} 5 \leq \mathrm{x} \mathrm{kWh}-$ solar energy production

$\mathrm{x} 14 \leq \mathrm{x} \mathrm{kWh}$ - energy production from biomass.

Model optimization with this objective function gives the following solutions.

TABLE 1. Solution to the optimization model

TABELA 1. Rozwiązanie modelu optymalizacji

\begin{tabular}{|l|c|c|c|c|c|c|c|c|c|c|c|c|c|c|c|}
\hline Types of energy & $\mathrm{x} 1$ & $\mathrm{x} 2$ & $\mathrm{x} 3$ & $\mathrm{x} 4$ & $\mathrm{x} 5$ & $\mathrm{x} 6$ & $\mathrm{x} 7$ & $\mathrm{x} 8$ & $\mathrm{x} 9$ & $\mathrm{x} 10$ & $\mathrm{x} 11$ & $\mathrm{x} 12$ & $\mathrm{x} 13$ & $\mathrm{x} 14$ & $\mathrm{x} 15$ \\
\hline Energy production & $\mathrm{x}$ & $\mathrm{x}$ & $\mathrm{x}$ & $\mathrm{x}$ & $\mathrm{x}$ & $\mathrm{x}$ & $\mathrm{x}$ & $\mathrm{x}$ & $\mathrm{x}$ & $\mathrm{x}$ & $\mathrm{x}$ & $\mathrm{x}$ & $\mathrm{x}$ & $\mathrm{x}$ & $\mathrm{x}$ \\
\hline Energy resources & $\mathrm{x} 16$ & $\mathrm{x} 17$ & $\mathrm{x} 18$ & $\mathrm{x} 19$ & $\mathrm{x} 20$ & $\mathrm{x} 21$ & $\mathrm{x} 22$ & $\mathrm{x} 23$ & $\mathrm{x} 24$ & & & & & & \\
\hline Crop size & $\mathrm{x}$ & $\mathrm{x}$ & $\mathrm{x}$ & $\mathrm{x}$ & $\mathrm{x}$ & $\mathrm{x}$ & $\mathrm{x}$ & $\mathrm{x}$ & $\mathrm{x}$ & & & & & & \\
\hline
\end{tabular}

Source: own study based on the model.

A description of the practical use of the model of the selected territorial unit is provided in the article (Rabe et al. 2019a).

\section{Summary}

The use of the lexicographic method to build a mathematical model of obtaining energy that takes the potential for the development of renewable energy into account, taking the criteria of sustainable development into account, i.e. economic, ecological, social. It can be a tool for decision-makers to indicate the direction of development of energy production in local government units: poviats and communes.

In the model of obtaining renewable energy using the lexicographic method, it is important to study various types of technologies that may appear in the system. And also, global, EU and national conditions regarding access to energy raw materials, legal and ecological regulations should be taken into account. 


\section{References}

Bartosiewicz, S. 1990. Econometric (Ekonometria). Warszawa: PWE, 14 pp. (in Polish).

Bhowmik et al. 2017 - Bhowmik, Сн., Bhowmik, S., RaY, A. and Pandey, K.M. 2017. Optimal green energy planning for sustainable development: A review. Renewable and Sustainable Energy Reviews Vol. 71, 796-813, pp. 134-136.

GLINKowsKa, B. 2010. Modeling in organization improvement processes - theoretical and methodological remarks (Modelowanie w procesach usprawniania organizacji-uwagi teoretyczno-metodyczne). Acta Universitatis Lodziensis, Folia Oeconomica 234, pp. 255-264 (in Polish).

JANKOwsKI, B. 1997. Modeling the development of the national energy system, taking into account the requirements for stabilizing the reduction of carbon dioxide emissions in Poland (Modelowanie rozwoju krajowego systemu energetycznego z uwzględnieniem wymagań stabilizacji redukcji emisji dwutlenku węgla w Polsce). Warszawa: IPPT PAN, 217 pp. (in Polish).

KASPRZAK, T. 1992. Systems for supporting multi-criteria decisions (Systemy wspomagania decyzji wielokryterialnych). Warszawa: UW Publishing Houses, 173 pp. (in Polish).

KonarzewsKa-Gubata, E. 1980. Programming with multiple purposes (Programowanie przy wielorakości celów). Warszawa: PWN, 222 pp. (in Polish).

Krog, L. and Sperling, K. 2019. A comprehensive framework for strategic energy planning based on Danish and international insights. Energy Strategy Reviews Vol. 24, pp. 83-93.

MALICKI, M. 1993. Lexical method in farm production planning (Metoda leksograficzna $w$ planowaniu produkcji gospodarstwa rolnego). Szczecin: AR Szczecin, pp. 112-115 (in Polish).

MALICKI, M. 1999. Risk in planning feed management (Ryzyko w planowaniu gospodarki paszowej). Szczecin: AR Szczecin, 44 pp. (in Polish).

MoKRZYCKI, E. 2003. The idea of distributed generation. A new look at the environment (Idea generacji rozproszonej. Nowe spojrzenie na środowisko). Nafta \& Gaz Biznes, pp. 1-5 (in Polish).

RABE et al. 2019a - RABE, M, StreimikiEnE, D. and BiLAn, Y. 2019a. EU carbon emissions market development and its impact on penetration of renewables in the power sector. Energies 12(15), DOI: 10.3390/ en12152961, pp. 1-20.

Rabe et al. 2019b - Rabe, M., Streimikiene, D. and Bilan, Y. 2019b. The Concept of Risk and Possibilities of Application of Mathematical Methods in Supporting Decision Making for Sustainable Energy Development. Sustainability 11, DOI: 10.3390/su11041018, pp. 5-8.

SkoczKowski, T. 2007. Development of Polish legal regulations in the aspect of distributed energy sources (Rozwój polskich regulacji prawnych $w$ aspekcie rozproszonych źródet energii). Seminar "Integration of distributed generation with the Polish Power System", Warszawa, 19.04.2007, pp. 6-9 (in Polish).

SobCZyK et al. 2011 - SobczYK, E., WotA, A. and KrĘżoŁeK, S. 2011. The use of mathematical multicriteria methods to choose the optimal variant of the source of hard coal extraction (Zastosowanie matematycznych metod wielokryterialnych do wyboru optymalnego wariantu źródła pozyskania węgla kamiennego). Gospodarka Surowcami Mineralnymi - Mineral Resources Management Vol. 27, Iss. 3, pp. 51-68 (in Polish).

Theo et al. 2017 - Theo, W.L., Lim, J.S., Ho, W.S., Hashim, H. and Lee, C.T. 2017. Review of distributed generation (DG) system planning and optimisation techniques: comparison of numerical and mathematical modelling methods. Renewable \& Sustainable Energy Reviews 67, pp. 531-573. 


\section{Model matematyczny produkcji energii, wykorzystywany do wspierania polityki energetycznej w jednostkach samorządu terytorialnego}

\section{Streszczenie}

Proces agrarny obejmuje wiele zjawisk i wydarzeń industrialnych. Celem ekonomii jako nauki jest właśnie wykrycie i opisanie związków między różnymi mechanizmami rynkowymi. Zjawiska te można przedstawić jako „dążenie do opisania rzeczywistości w kategoriach układów, ich składników i relacji, zarówno między składnikami układu, jak i między różnymi układami” (Jankowski 1997). Energetyka, spośród wielu obszarów gospodarki narodowej, jest dziedziną szczególną, a produkty tego sektora mają zasadniczy wpływ na gałęzie gospodarki i występujące w nich mechanizmy działania. Publikacja poświęcona jest konstrukcji matematycznego modelu, stosowanego do wspierania polityki energetycznej jednostek samorządu terytorialnego. Celem badania jest zbudowanie matematycznego modelu produkcji energii z uwzględnieniem potencjału rozwojowego energii odnawialnej, a także zaproponowanie władzom regionalnym pożądanego kierunku rozwoju polityki energetycznej w analizowanych okresach oraz zaoferowanie modelu do kreowania polityki energetycznej w innych jednostkach samorządu terytorialnego: powiatach, gminach. Dotychczas niewielu autorów kompleksowo zajmowało się tą problematyką. Dotąd nie ukazały się szczegółowe badania dotyczące zagadnień rozwoju energii odnawialnej i stosowania metod matematycznych w budowie modelu produkcji energii w jednostkach samorządu terytorialnego. Podjęte badania stanowią wkład w rozwój wiedzy o alternatywnych źródłach energii w obszarze energetycznym.

SŁowA KLUCZOWE: odnawialne źródła energii, metoda leksykograficzna, matematyczny model produkcji energii 
